\title{
EFL learners' perception toward the use of interactive e-book in grammar class
}

\author{
Fitrawati \\ Faculty of Languages and Art, Universitas Negeri Padang, Indonesia
}

\section{Chikal Lexsti Rahmadani}

Faculty of Languages and Art, Universitas Negeri Padang, Indonesia

\section{Hermawati Syarif}

Faculty of Languages and Art, Universitas Negeri Padang, Indonesia

email:fitra_sasing@yahoo.com, chikallexstirahmadani06@gmail.com, hermawati_sy@yahoo.com

\begin{abstract}
The use of multimedia has become the demand of this 21st-century education where the material used has to include more technological devices and it also supports student-oriented learning methods. The use of this kind of technology also can be applied in English lessons like grammar. In the English Department of Universitas Negeri Padang, interactive e-book has been used in the grammar class, specifically in advanced grammar class for students in the academic year 2018. This study aimed to analyze students' perceptions toward the use of this interactive e-book in advanced grammar class. The population of this study consist of the students in the English Department from the 2018 academic year. The samples are selected through purposive sampling whereby the sample was the class that used interactive e-book in their advanced grammar class. The instrument for this study was a questionnaire, which is divided into 3 sections: interface, interactivity, and material. The data was analyzed using descriptive statistical calculation. The result of this study was students had a positive perception toward the use of interactive e-book in advanced grammar class. Hence, the students' perceptions can be used to improve the interactive e-book used in teaching and learning process grammar.
\end{abstract}

Keywords: Perception, Interactive e-book, Grammar, EFL learners

\section{INTRODUCTION}

One of the important elements in language teaching and learning is grammar. Grammar is a set of language laws (Choo and Kwon, 2017). Yule (2010) also stated that grammar is the method of describing the structure of phrases and sentences in such a manner that all grammatical sequences in a language are taken into consideration and all ungrammatical sequences are excluded. The grammar will influence language mastery. Thus, grammar is an element that needs to be studied in depth when studying English officially. The learners must have sufficient grammar to have excellent language abilities (Effendi et al, 2017). However, 
grammar is considered an unattractive subject at school because it is difficult. Even when students study it years at university, there are still grammatical mistakes in their sentences or papers.

This condition happened not only because of the difficulty of grammar itself but also the way grammar is taught as the subject. Grammar is still taught using talk and chalk method and more teacher-oriented where the lecturer explained the material and wrote the point of explanation on the whiteboard while students listen. The material used in grammar class is also usually a thick printed book. It can easily create boredom to students, then they would lose focus and try to do something else to keep away their boredom. Usually, they play with their gadgets or open social media. This situation might affect students' learning and achievement because they did not pay attention to the lesson. Also, the method used makes the class less student-oriented although student-centered teaching was one of the demands stated in the Indonesian curriculum.

One of the ways to create a student-oriented class is to maximize the use of technologies such as multimedia in the classroom. The use of multimedia is believed to increase students' learning and achievement (Adeniyi et al, 2016). The use of multimedia also becomes the demand of 21st-century education where the teachers need to use more technological devices and it also supports student-oriented learning methods. The use of this kind of technology also can be applied in English lessons like grammar. Learners learn more from a combination of words and pictures than just words. The words do not necessarily need to be written. Words can be spoken or written, while pictures can be graphics of any kind. These graphics include images, pictures, animation, or video (Choo and Kwon, 2017).

Students are responsible for their learning when they use multimedia. They can interact with the content the way they like best and make learning more individualistic based on their ability (Neo and Kian, 2003). Students can learn without depending on time and place -they can create their pace in learning. It makes students easier to deeply understanding grammar. One of the multimedia application which can be used is interactive e-book. According to Bozkurt and Bozkaya (cited in Bozkurt and Bozkaya, 2015), Interactive e-books are mainly digital book formats in which users, digital books and the environment can interact extensively with each other. The aim of using this interactive e-book in advanced grammar is to make it suitable for students in this technology era and to simplify the complicated grammar and make it easier to understand by students (Fitrawati and Syarif, 2018).

The features provided in interactive e-book also can help them in learning such as the portability of the interactive e-books make it easy to access anytime and anywhere (Bozkurt and Bozkaya, 2015). Moreover, interactive e-books or e-books distributed through the internet are accessible, and also interactive - provide word search through the whole book or chapters, access to specific segments, and practice skill (Chen, 2015). These features are also included in interactive e-books quality criteria which are divided into some parts, such as the interface which shows the surface or the aesthetic side of the interactive e-books, the interactivity, and material provided which is suitable with the demand in the syllabus, and the exercises. These criteria support interactive e-books in helping students to learn advanced grammar.

Even though it says that the features can help students in learning, their perspective toward it is also important to be considered since they are the main user of this multimedia. It is important to see whether this technology is helping in real learning experience, especially their thoughts toward the features itself. It is because in some studies on students' perception toward interactive e-book or e-book, this book was not seen as the first source material in a classroom but a source of quick references (Chu, 2003). It was also not for serious reading and academic reasons (Abdullah and Gibb, 2008 and de Oliveira, 2012), and even some students preferred to use printed book rather than e-book despite the features that it has. Thus, 
exploring the students' perceptions about the features provided or the quality of interactive e-book is needed. It is to see their thoughts which can be used to improve the book. Hence, this research is focused on the criteria provided in the advanced grammar interactive e-books whether they were appropriate for students or not. The quality criteria for interactive e-book in this research is divided into three aspects: interface, interactivity, and teaching material.

\section{BACKGROUND OF THE STUDY}

The use of books in teaching and learning process is important because it stores the information which is needed by students. However, the growth of the technology nowadays and the demand of the use of it in the classroom, make the innovation in teaching materials and tool like books developed. The transformation from traditional to digital materials has been visible in many parts of life including the books industry, from the printed traditional books into digital books. The one which is more well-know is e-book.

There are some definitions of e-book. Hawkins (2000) defines e-books as the technology that provides the content of printed book which is available in electronic mode. Anuradha and Usha (cited in Chen, 2015) define e-books as an electronic text for the same purpose as a standard printed book. Suyanto (cited in Lestari et. al, 2018) defines e-book as an interactive book using electronic tool which includes information to create text or picture.

From the definitions, it can be concluded that e-books are the electronic version of printed book which can be displayed on computer or any electronic devices which includes screen. However, other definitions also show that e-books are not only the digital version of printed book, it also has special features which differs e-books with its printed version.

According to Nelson (2008) e-books are electronic books which can be digitally read on the computer screen, specific e-books reader, personal digital assistant, or even a mobile phone. However, e-books has special distinctions which make it different with other scanned printed book. The distinction refers to the addition of animation, simulations, videos, audios, and instance.

Then, according to Jeong (2010), the word e-book is used to describe a text analogous to a book digitally displayed on a computer screen, a personal digital assistant or a reader specifically designed; it may include text, graphics, video, animation and/or sound. The e-book is a new medium for accessing digital information, focusing on the benefits of electronic reading and offering many of the advantages of paper books. Jeong includes search ability and availability for the special features in e-books.

The term interactive in interactive e-book refers to reciprocal activity between a learner and a multimedia learning system, in which the [re] action of the learner is dependent upon the [re]action of the system and vice versa (Domagk, et, al., 2010). In other words, there are interaction between the users and the digital books. Bozkurt and Bozkaya (2013) define interactive e-book as "Essentially digital e-book format which user, the digital book, and the environment can interact reciprocally at a high level; digital book elements can communicate and interact among themselves and environment as well as users, and many communication channels are put in the use at one and the same time." It can be seen that, interactive e-book is not only the e-book which is complimented by interactive multimedia, they are also integrated together and interact with the user.

To see whether the interactive e-book is appropriate for supporting students in learning, the quality criteria which defined the interactive e-book are used. There are several quality criteria in interactive e-book such as the interface where the users or students connect with the system, the interactivity where students can interact with the system, and the content or material used in interactive e-book which is suitable with students. Interface of interactive 
e-book is the place where the students or users can interact with the system. Interface is not just aesthetic part of interactive e-book but also the placement of components. Bozkurt and Bozkaya (2015) define the interface as the intersection point where user and interactive e-book contact; as the showcase or the face of the interactive e-book. Interface is the bridge between the users and the computer to connect and effect each other.

Bozkurt and Bozkaya (2015) mention about the criteria of interactive e-book which they divide into some dimensions, one of them is interface dimension which is also in line with the term interface in this study. They divide it into some criteria under the sub-sections: first, for the ease of interface use include the user friendly, quick access by navigation tools, bookmarking and search ability; second is about customization and autonomy which includes authoring support; third is about the interface design, esthetic and consistency which include simple and straight-forward layout design, readable without hurting eyes, balanced design for the amount of information, consistency of buttons, icons, and menu items, consistency of interface areas, consistency of labels and messages, and providing balance color for layout; fourth is universal design for accessibility which focuses on accessibility for individual with special needs; five is about support services which include update for the interactive e-book content; and the last is about the layout frame design which include the physical techniques in layout frame design. Wuang and Huang, Lim et. al., and Yeh in Oyaid and Alshaya (2019) describe the criteria of interface interactive e-book as: there are options related to change the font type; font maximizing and minimizing; marking hyperlinks in a different color; highlighting of significant sections; taking notes on the pages of the book; pointer to the user's location within the book; clear and understandable icons to the user; searching for a specific word through inserting it into the search box; and navigating to specific pages through inserting its number in the search engine.

The term interactivity is related to the interaction that happens between the user and the computer. The action taken from one party can affect the other and vice versa. According to Domagk et al (2010), based on those primary orders, the definition of interactivity in term of multimedia learning can be divided as "Interactivity in the context of computer-based multimedia learning is a reciprocal activity between a learner and a multimedia learning system, in which the [re]action of the learner is dependent upon the [re]action of the system and vice versa." It shows the relationship between the learners and the learning system which becomes dynamic.

According to Moreno and Mayer (2007) there are five common types of interactivity: dialoguing, controlling, manipulating, searching, and navigating. In interactivity by dialoguing, learner gets a question and answer or feedback to their input. For example, learner can ask help from the screen or click on a hyperlink to get an additional information. In interactivity by controlling, learner control pace and/or the presentation order. For example, learner can use the play/pause or forward button while watching a video or narrated animation. In interactivity by manipulating, learner can control the presentation features, such as setting conditions before the simulation runs, zooming in or out, or moving objects around the screen. In interactivity by searching, the learner can engage in searching for information, such as entering a query, receiving options, choosing an option, and so on, such as searching the Internet. In interactivity by navigating, the learner will decide the content of the learning series by choosing from different sources, such as a menu button. These types of interactivity are related to each other. Only navigation, for example, or searching type of interactivity cannot create interactive learning environment. Hence, all of the types of interactivity are important to be added into a multimedia learning in order to support students-centered learning.

There are four levels of interactivity for multimedia such as interactive e-book according to Valley (2016). First, level 1 for passive interactivity which refers to the general action which aims for a course to function correctly. It includes navigation, page animation, 
object animation, and a combination of true and false and multiple choice questions. Then, level 2 for limited interactivity which also includes the action on the passive level and other additional features. In this level, learners have more control over the course because of these features, such as clickable graphics, audio, video, basic activity like drag and drop, and modifications to navigation like a drop down menu or links to external resource. Level 3 for moderate interactivity. This level combines passive and limited interactivity. It gives learners more complex course and give the developers more chance to customize the program. The features included in this level such as animation videos, customized audio, intermediate level simulations, scenario-based examples, and flash style animation. The last level is simulation interactivity. In this level, all other previous level is combined along with some new types of interaction where learners experience the highest level of engagement. This level usually includes gamification, advanced or 3D simulations, a variety of multimedia, and a guide or an avatar.

In the case of teaching material, there is no significant difference between materials provided in the interactive e-book and the printed one. According to Prasetya et al (2018), digital books can be the electronic version of printed book which might include digital data content such as text, images, animation, audio, video and are accessed through electronic devices such as computers or mobile phones. In short, the content in the printed books is also in electronic version or e-book. It means that the content in interactive e-book has to follow the requirement of books used in the classroom. The material should follow the curriculum, include the interactivity and multimedia, use inductive approach, motivate students, give further explanation, and comply with the language suitability (Hvala, Kobal and Zmazek, and E-um team in Zmazek et al, 2012).

\section{METHODOLOGY}

This research was conducted under the English Department, Universitas Negeri Padang in 2019 to investigate students' perception towards interactive e-book used in advanced grammar class. The sample of this research consist of English Department students of Universitas Negeri Padang in the academic year 2018. There were two advanced grammar classes which used interactive e-book for teaching and learning. Hence, these two classes were taken as sample which consisted of 59 students. The data was collected using a questionnaire adapted from Garinger (2002), Bozkurt and Bozkaya (2015), Bozkurt, Okur, and Karadeniz (2016), Elyazgy (2016) and Fitrawati dan Hermawati Syarif (2018), and Oyaid and Alshaya (2019). The questionnaire was validated by an expert from the Education Technology major and English Department specifically grammar expert. The questionnaire consists of three components; the interface (15 statements), the interactivity (13 statements), content (teaching material (20) and learning exercise (7)), and the practicality (16 statements) of the interactive e-book where the total statements were 71. The questionnaire was conducted with the English Department students. It was made in Google Form and the link was shared through email or social media. Also, the questionnaire used the Linkert scale which consists of four points, strongly agree, agree, disagree, and strongly disagree. 


\section{FINDINGS AND DISCUSSION}

\section{Findings from Questionnaire}

The findings are presented according to three components. First the interface of the interactive e-book. Second, the interactivity of interactive e-book. Finally, teaching material of interactive e-book.

Table 1. Students' responses toward interface of interactive e-book

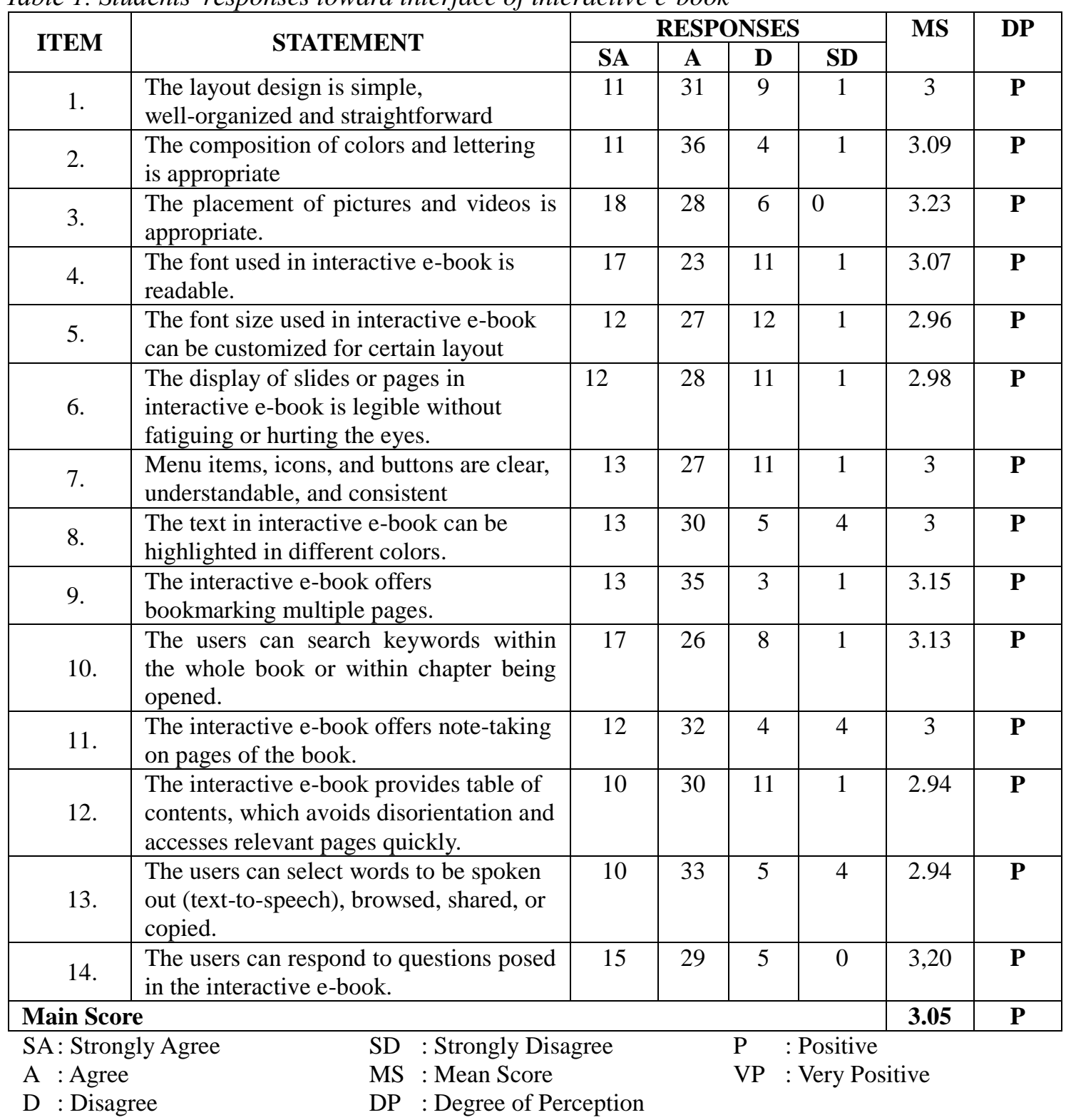

From the table 1 above, the mean score of perception for interface of interactive e-book is 3.05 which is considered to be positive. From all statements in this section, the score is also considered to be positive; however, the higher score (3.23) is from the statement, the placement of pictures and videos is appropriate. It means that students agree that the place to drop the media such as pictures and videos on interactive e-book is important. Meanwhile, the lowest score from this section is found in two statements. They are about providing table of content to avoid disorientation and selecting words to be spoken out, browsed, shared, or copied whereby 
both statements recorded the score 2.94. It seems that students find the table of content features cannot direct them quickly to the exact page that they want to open. Probably they have to slide the page to find to the target page. Moreover, for selecting words to be spoken out, browsed, shared, or copied, students probably find out that some selecting words cannot be either spoken out, browsed, shared, or copied. However, there are no further explanation or comment from students on these statements.

On the other hand, some comments are found related to the readability of font used in interactive e-book. The negative comment stated by students is they found that the font used in the book is small. Hence, students cannot read the sentences properly because of that especially if the screen is in the landscape mode. From these comments, the customizable font tool has to be considered. All in all, students have positive perception toward the interface of the advanced grammar of interactive e-book.

Table 2. Students' responses toward interactivity of interactive e-book

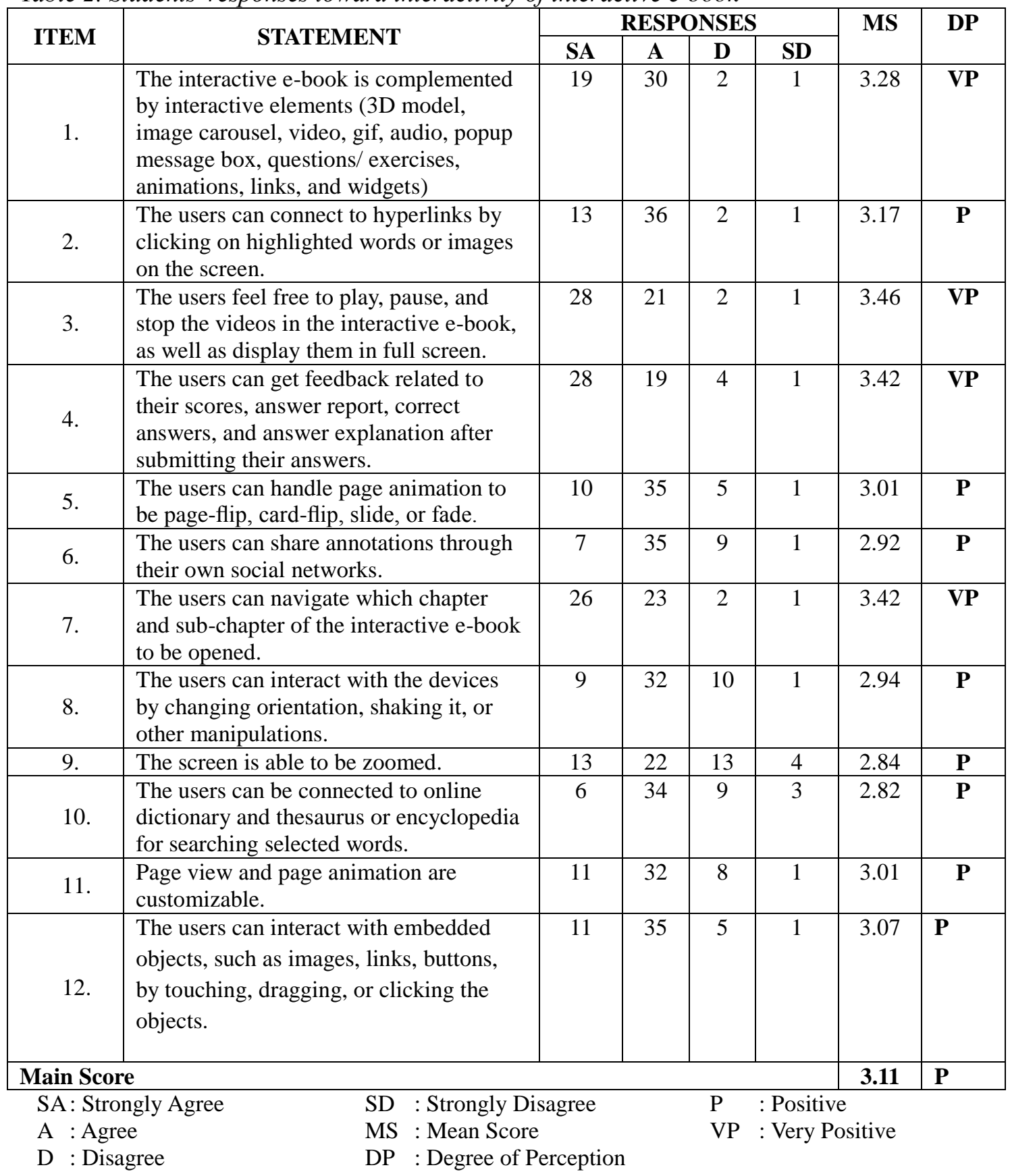


Based on the table 2 above, the mean score for the interactivity of advanced grammar interactive e-book is 3.11. It means that students have positive perception toward the interactivity part in interactive e-book. The highest score which is found in this section is from the statement 'The users feel free to play, pause, and stop the videos in the interactive e-book, as well as display them in full screen' with 3.46 score. It seems students agree that they can control the media which is provided in the interactive e-book. Meanwhile the lowest score come from the statement 'The users can be connected to online dictionary and treasures or encyclopedia for searching selected words' with 2.82 score. Probably students find some words that they selected could not directly be connected to the dictionary. It might be because of the lack of the internet connection or error. It can also be because of some word provided in interactive e-book cannot be selected properly. There is no other further explanation or comment from students related this statement.

Nevertheless, some comments are found related to the ability of zooming screen. Students said that the zoom tool could not be operated well, so the screen could not be seen clearly. Since zoom tool is provided to make students feel easy to focus on the object that they want in the screen, this tool is important for students when they use the book especially for studying. Overall, students also have good perception toward the interactivity of advanced grammar interactive e-book.

Table 3. Students' responses toward the material of interactive e-book

\begin{tabular}{|c|c|c|c|c|c|c|c|}
\hline \multirow{2}{*}{ ITEM } & \multirow{2}{*}{ STATEMENT } & \multicolumn{4}{|c|}{ RESPONSES } & \multirow{2}{*}{ MS } & \multirow{2}{*}{ DP } \\
\hline & & SA & $\mathbf{A}$ & D & SD & & \\
\hline 1. & $\begin{array}{l}\text { The materials are convenient with the } \\
\text { curriculum and syllabus. }\end{array}$ & 24 & 23 & 3 & 2 & 3.32 & VP \\
\hline 2. & The materials are explicit. & 13 & 33 & 4 & 2 & 3.09 & $\mathbf{P}$ \\
\hline 3. & The materials are easy to be understood. & 17 & 29 & 5 & 1 & 3.19 & $\mathbf{P}$ \\
\hline 4. & $\begin{array}{l}\text { The materials are provided } \\
\text { systematically. }\end{array}$ & 15 & 32 & 3 & 2 & 3.15 & $\mathbf{P}$ \\
\hline 5. & $\begin{array}{l}\text { The materials are provided in simple } \\
\text { terms. }\end{array}$ & 12 & 30 & 8 & 2 & 3 & $\mathbf{P}$ \\
\hline 6. & $\begin{array}{l}\text { Examples provided are relevant with the } \\
\text { materials. }\end{array}$ & 17 & 28 & 6 & 1 & 3.17 & $\mathbf{P}$ \\
\hline 7. & $\begin{array}{l}\text { The interactive e-book contains } \\
\text { comprehensive materials. }\end{array}$ & 17 & 30 & 4 & 1 & 3.21 & $\mathbf{P}$ \\
\hline 8. & $\begin{array}{l}\text { The interactive e-book prepares the } \\
\text { materials with a theoretical framework } \\
\text { that supports learning objectives. }\end{array}$ & 14 & 34 & 3 & 1 & 3.17 & $\mathbf{P}$ \\
\hline 9. & $\begin{array}{l}\text { The materials in the interactive e-book is } \\
\text { integrated with other services and } \\
\text { sources of information. }\end{array}$ & 9 & 36 & 6 & 1 & 3.01 & $\mathbf{P}$ \\
\hline 10. & $\begin{array}{l}\text { The materials are appropriate for } \\
\text { characteristics of the target audience. }\end{array}$ & 7 & 38 & 5 & 2 & 2.96 & VP \\
\hline 11. & The materials are presented attractively. & 18 & 27 & 6 & 1 & 3.19 & $\mathbf{P}$ \\
\hline 12. & $\begin{array}{l}\text { The video material used in interactive } \\
\text { e-book is relevant to the topics being } \\
\text { discuss. }\end{array}$ & 21 & 28 & 2 & 1 & 3.32 & VP \\
\hline 13. & $\begin{array}{l}\text { The materials help learners to develop } \\
\text { confidence. }\end{array}$ & 10 & 33 & 7 & 2 & 2.98 & $\mathbf{P}$ \\
\hline 14. & $\begin{array}{l}\text { Topics in interactive e-book are relevant } \\
\text { and useful for learners. }\end{array}$ & 21 & 27 & 2 & 2 & 3.28 & VP \\
\hline 15. & $\begin{array}{l}\text { The materials facilitate learners to make } \\
\text { discoveries for themselves. }\end{array}$ & 15 & 31 & 5 & 1 & 3.15 & $\mathbf{P}$ \\
\hline 16. & $\begin{array}{l}\text { The materials expose learners to } \\
\text { language in authentic use. }\end{array}$ & 12 & 36 & 3 & 1 & 3.13 & $\mathbf{P}$ \\
\hline
\end{tabular}




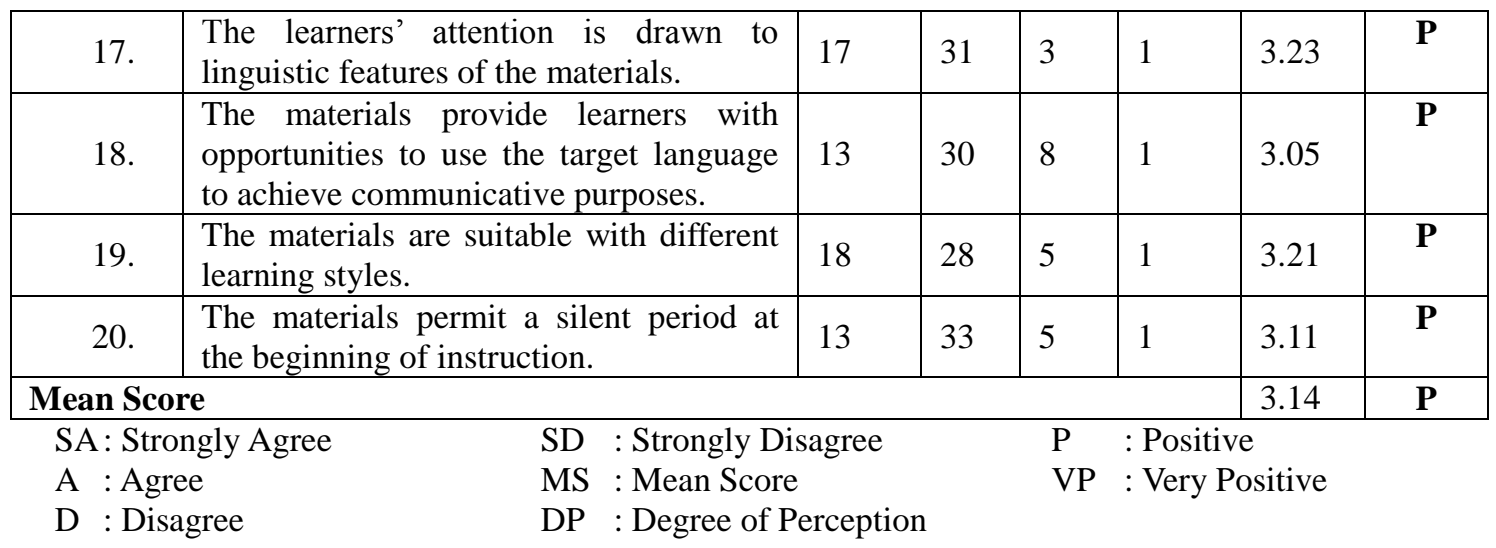

According to table 3 above, the mean score for the teaching material in advanced grammar interactive e-book is high which is 3.14 score. It means that students perceived positively toward the teaching material provided in the book. For the highest score in this section, the statements 'The materials are convenient with the curriculum and syllabus' and 'The video material used in interactive e-book is relevant to the topics being discuss' get the same score which is 3.32. It shows that students believe the material provided in the interactive e-book is related and in the same line with the curriculum and syllabus of advanced grammar in English department. Then, they also seems to agree that the videos provided in every chapters in the interactive e-book are related to the topics being discussed. It shows that the relevant materials are important.

Meanwhile, the statement 'The material are appropriate for characteristics of the target audience' gained the lowest score among all the statements with 2.96 score. Even though the score is considered as positive, it shows that some students believe the materials have to be related to their characteristics and it is something which also has to be considered for students' better understanding. Nonetheless, there is no further explanation or comment from students related to this statement and also for other statements in this section.

\section{DISCUSSION}

The discussion of the main findings is presented in table 4 below.

Table 4. Research result

\begin{tabular}{|c|l|c|c|}
\hline Sections & $\begin{array}{c}\text { Mean } \\
\text { Score }\end{array}$ & $\begin{array}{c}\text { Degree of } \\
\text { Perception }\end{array}$ \\
\hline 1. & Interface of Interactive E-book & 3.05 & $\mathbf{P}$ \\
\hline 2. & The interactivity of Interactive E-book & 3.11 & $\mathbf{P}$ \\
\hline 3. & $\begin{array}{l}\text { The teaching material in Interactive } \\
\text { E-book }\end{array}$ & 3.14 & $\mathbf{P}$ \\
\hline Average & $\mathbf{3 . 0 1}$ & $\mathbf{P}$ \\
\hline
\end{tabular}

The aim of the study was to analyze students' perception toward interactive e-book used in advanced grammar seeing from the four aspects: interface, interactivity, content, and practicality. As presented in the finding above, students perceived positively in all aspects of advanced grammar of interactive e-book. Among all aspects, the teaching material from content aspect got the highest score with 3.14. It showed that the participant still believed the materials provided in interactive e-book could support them in learning. From the finding, it can be stated that the most important thing in teaching material section based on students' 
perception is the suitability of material with the curriculum and syllabus. This finding supported by Venegas (2006) revealed that the learning material has to fulfill the objectives of the study which is stated in the curriculum and syllabus. It means that if the material is in line with and related to the curriculum and syllabus, the objective of the study also can be reached. Sari et al (2014) also confirmed that the materials which have to be implemented and how they are used in the teaching and learning process are specified by the syllabus. It clarifes that the suitability of materials with curriculum and syllabus is important.

From the data, it can be concluded that if the materials do not match with students' characteristics, then it is considered to be unsuitable. It is in line with Ashar (2014) who reported that unsuitable materials can be defined as materials that do not match the learner's needs and characteristics, such as learners' age, lever, and learning style. It is also supported by Rahadian and Budiningsih's (2017) explanation which stated that all types of students' characteristics ideally have to be considered by teacher because it can influence the choice of other instructional method variables.

Then, students also perceived quite highly of the interactivity aspect. It shows that students see the interactive e-book has enough interactive features to support their learning. From the finding, it can be stated that the most interactive part based on students perception is that they can control the media provided. Based on the interactivity level for multimedia e-learning design mentioned by Valey (2016) this kind of feature is in level two which is defined as limited interaction where the features give learners more control on the learning and gets more involved with the course. However, in line with Askar's (2014) observation in his research, students prefer the e-book without much interactivity due to the lack of usage of prior knowledge, feeling attacked to it, and lack of understanding in their offerings. Nevertheless, there is also a part which has to be considered in this aspect. The interactive e-book feature, zoom ability or zoom control has been commented by students because it could not zoom object or screen clearly. Based on the types of interactivity stated by Moreno and Mayer (2007), zoom ability is included into the presentation features, especially for zooming in and out, which learners can control. It also could be included into the limited interaction features. The lack of this ability can affect students' control and involvement in the course. Hence, this part of interactivity has to be improved.

This research also see the interface aspect of advanced grammar interactive e-book. Even though it has the lowest mean score from others, students still perceived positively toward it. From the finding, students seemed to believe the interface aspect has already showed the visual side of the interactive e-book and the most focus one based on students' perception is the arrangement of element such as media provided, in this case videos, in interactive e-book. Considering the arrangement of the elements provided is important to make sure all elements like media are in order. Bhaskar et al (2011) also mentioned that the users of interface expect the elements on screen are arranged in order and clutter-free. It is also to make sure that all the elements placed upon their purpose.

The other thing which also has to be considered is the readable font in interactive e-book. It received some negative comments by students due to lack of readability because of the small font in the display screen. It is supported by Ali et al (2013) which stated some factors that can affect readability of text on a computer screen such as font type and size.

\section{CONCLUSION AND RECOMMENDATION}

The use of technology in the classroom is such as fresh air for the teaching and learning process. In this era where everything is surrounded by technology, interactive e-book gives an alternative to support teaching and learning. From the study, a lot of improvement has to be 
done to the interactive e-book which was used in advanced grammar. The three components of criteria-interface, interactivity, and material, have received positive perceptions from students. As mentioned earlier, getting students' perceptions toward interactive e-book is important for the developers to create a better interactive e-book and to see which parts have to be provided and improved to support them in using interactive e-book. Students' point of views are important since they are the users in the process.

\section{REFERENCES}

Abdullah, N., \& Gibb, F. (2008). Students' attitudes towards e- books in a Scottish higher education institute: part 2. Library Review, 57, 676-689. Retrieved October 13, 2019, from https://www.emerald.com/insight/content/doi/10.1108/00242530810911798/full/htm1

Adeniyi, O. F., Olowoyeye, A. C., \& Onuoha, U. D. (2016). The Effect of Interactive Multimedia on English Language Pronunciation Performance of Pupils in the Nigerian Primary Schools. Research on Humanities and Social Sciences, 6, 71-78. Retrieved October 13, 2019, from https://pdfs.semanticscholar.org/d70e/26f24be6ca6e80b457eaa05543067c62054f.pdf

Alshaya, H., \& Oyaid, A. (2017). Designing and publication of interactive e-book for students of princess Norah bint Abdulrahman university: An empirical study. Journal of Education and Practice, 8(8), 41-57. Retrieved July 7, 2019, from https://files.eric.ed.gov/fulltext/EJ1138827.pdf

Askar, A. (2014). Interactive Ebooks as a Tool of Mobile Learning for Digital-Natives in Higher Education: Interactivity, Preferences, and Ownership. AECT, 7-14. Retrieved October 13, 2019, from https://members.aect.org/pdf/Proceedings/proceedings14/2014/14_02.pdf

Bhaskar, N. U., Prathap Naidu, P., Babu, R. C., \& Govindarajulu. (2011). Principle of Good Screen Design in Websites. International Journal of Human Comouter Interaction (IJHCI). 2(2). 48-57.

Bozkurt, A., \& Bozkaya, M. (2015). Evaluation Criteria for Interactive E-books for Open and Distance Learning. International Review of Research in Open and Distributed Learning, 16, 58-82. Retrieved July 7, 2019, from https://files.eric.ed.gov/fulltext/EJ1077792.pdf

Chen, Y. (2015). Perceptions of E-books Among Students and Instructors in Higher Education. Montreal, Quebec, Canada.

Chen, Y., Carliner, S., Martinez, S. G., \& Davidson, A.-L. (2019). Exploring Perceptions of E-books Among CEGEP Students and Faculty. Canadian Journal of Learning and Technology, 45, 1-29. Retrieved from https://www.learntechlib.org/p/208591/

Choo, \& Kwon, V. (2017). Using Multimedia Interactive Grammar to Enhance Possessive Pronouns among Year 4 Pupils. Journal of English Education, 2, 34-42. Retrieved from http://usnsj.com/index.php/JEE/article/view/2.1.34-42

Chu, H. (2003). Electronic books: viewpoints from users and potential users. Library Hi Tech, 21(3), 340-346.

de Oliveira, S. (2012). E-textbooks usage by students at Andrews University study of attitudes, perceptions, and behaviors. Library Management, 33(8/9), 536-560.

DOI: http://10.1108/01435121211279894

Domagk, S., Schwartz, R. N., \& Plass, J. L. (2010). Interactivity in Multimedia Learning: An integrated model. Computer in Human Behavior, 1-11. Retrieved October 13, 2019, from https://www.sciencedirect.com/science/article/pii/S0747563210000439

Effendi, M. S., Rokhyati, U., Rachman, U. A., Rakhmawati, A. D., \& Pertiwi, D. (2017). A Study on Grammar Teaching at an English Education Department in an EFL Context. International Journal on Studies in English Language and Literature (IJSELL), 5(2), 42-46. Retrieved July 9, 2019, from https://www.arcjournals.org/pdfs/ijsell/v5-i1/5.pdf

Elyazgi, M. G., Nilashi, M., Ibrahim, O., Rayhan, A., Elyazgi, S. (2016). Evaluating the Factors Influencing E-book Technology Acceptance. Journal of Soft Computing and Decision Support Systems. 3(2). 11-25. 
Fitrawati, \& Syarif, H. (2018). Pengembangan Media E-Book Ineraktif pada Mata Kuliah Advance Grammar di Jurusan Bahasa dan Sastra Inggris Universitas Negeri Padang (pp. 1-65, Rep.). Padang.

Huang, H. C. (2012). E-reading and e-discussion: EFL learners' perceptions of an e-book reading program. Computer Assisted Language Learning, 23. Retrieved October 13, 2019 from https://www.researchgate.net/publication/254217029 E-reading and e-discussion EFL learn ers'_perceptions_of_an_e-book_reading_program

Jeong, H. (2012). A Comparison of the Influencer of Electronic Books and Paper Books on Reading Comprehension, Eye Fatigue, and Perception. Electronic Library. 30(3). 390-408. Retrieved April 28, 2019, from https://www.emerald.com/insight/content/doi/10.1108/02640471211241663/full/html

Kumar, R. (2011). Research Methodology (Third ed.). London: SAGE Publication. Retrieved April 28, 2019 ,

from http://www.sociology.kpi.ua/wp-content/uploads/2014/06/Ranjit_Kumar-Research_Methodol ogy_A_Step-by-Step_G.pdf

Learners' Dictionary. (2019). Retrieved October 13, 2019, from http://www.learnersdictionary.com/definition/display

Moreno, R., and Mayer, R. (2007). Interactive Multimodal Learning Environments. Educational Psychology Review. 19(3). 309-326. Retrieved Nov 9, 2019, from https://link.springer.com/article/10.1007/s10648-007-9047-2

Morris, N, P., and Lambe, J. (2017). Multimedia interactive eBooks in laboratory bioscience education. Higher Education Pedagodies. 2(1). 28-42. Retrieved Nov 9, 2019, from https://www.tandfonline.com/doi/pdf/10.1080/23752696.2017.1338531?needAccess=true

Nelso, M. R. (2008). E-Book in Higher Education: End of the Era of Hype?. Educause Review. 43(2). 40-56. Retrieved April 28, 2019, from https://er.educause.edu/articles/2008/3/ebooks-in-higher-education-nearing-the-end-of-the-era -of-hype

Neo, M., \& Neo, T. K. (2003). Students' Perception of Interactive multimedia mediated web-based learning: A Malaysia perspective. Ascilite 2008 Melbourne. Retrieved October 13, 2019, from https://pdfs.semanticscholar.org/6846/79e7aa9f2f88521cf630ee5bdf4d75cc6695.pdf

Rogers, Yvonne, et al. Interaction Design. Vol. 1, John Wiley\&Sons, Inc, 2002, https://arl.human.cornell.edu/879Readings/InteractionDesign-BeyondHuman-ComputerIntera ction.pdf

Sari, I., Ulgu, S., \& Unal, S. (2014). Materials Evaluation and Development: Styllabus, Setting, and Learner needs. International Journal of Teaching and Education. 2(2). 60-65.

Pandey, P., \& Pandey, M. M. (2015). Research Methodology: Tools and Techniques (First ed.). Romania, European Union: Bridge Center. Retrieved April 28, 2019, from http://www.euacademic.org/BookUpload/9.pdf

Prasetyo, E. (2014). Penggunaan Media Audio Visual (Slide Show Animation) dalam Pembelajaran Pendidikan Islam Kelas X di SMA Negeri 1 Ngunut Tahun Pelajaran 2013/2014 (Master's thesis, IAIN Tulungagung, 2014). Bandung. Retrieved from http://repo.iain-tulungagung.ac.id/128/

Valley, J. (2016). 4 Interactivity Levels for Game and Multimedia eLearning Design. Retrieved January 14 , 2020 , from https://www.trivantis.com/blog/4-interactivity-levels-game-multimedia-elearning-design/

Venegas, O. P. (2006). Ensuring the Effectiveness and Quality of Learning Materials: How to Use and Evaluate Literacy/ CE Materials. Regional Center for Educational Innovation and Technology. Retrieved October 13, 2019, from http://www.accu.or.jp/litdbase/pub/dlperson/pdf0106/rpp24_1.pdf

Woody, W. D., Daniel, D. B., \& Baker, C. A. (2009.). E-books or textbooks: Students prefer textbooks. Computer and Education, 55, 945-948. Retrieved from http://static.trogu.com/documents/articles/palgrave/references/woody $\quad$ E-books or textbooks-Studentsprefer textbooks.pdf 
Yule, G. (2010). The Study of Language (Fourth ed.). New York, United States: Cambridge University Press.Retrieved

from https://fac.ksu.edu.sa/sites/default/files/cambridge.the .study .of .language.4th.edition. apr_.2010.ebook-elohim.pdf

Zmazek, B., Lipovec, A., Pesek, I., Zmazek, V., Seveter, S., \& Regvat, J. (2012). WHAT IS AN E-TEXTBOOK? Metodicki Obzori, 2, 127-139. Retrieved July 7, 2019, from https://www.academia.edu/19097880/WHAT IS AN E-TEXTBOOK 